\title{
The abstract space and the alienation of political public space in the Middle East
}

Farzad Zamani

The University of Auckland, Auckland, New Zealand, and

Asma Mehan

University of Porto, Porto, Portugal

Political public

space in the

Middle East

483

Received 16 March 2019 Revised 15 July 2019 28 August 2019

17 September 2019

Accepted 17 September 2019

\begin{abstract}
Purpose - The purpose of this paper is to explain how abstract space of the State - universally and specifically within the context of Middle Eastern cities - aims to homogenise the city and eliminate any anomaly that threatens its power structure.

Design/methodology/approach - Through a historical and discourse analysis of these policies and processes in the two case studies, this paper presents a contextualised reading of Lefebvre's concept of abstract space and process of abstraction in relation to the alienation of political public spaces.

Findings - The paper proposes that regardless of these homogenising strategies being applied universally, they fail to respond to contextual particularities and therefore they - in a contradictory manner - may themselves produce a space of resistance and difference.

Originality/value - This paper focusses on Iran, the case of Tehran and Turkey, the case of Taksim Square and Gezi Park in Istanbul. Recent policies and strategies have been proposed and implemented to reduce, alienate and possibly neutralise the impacts of urban and political protests in these cities and socio-political contexts.
\end{abstract}

Keywords Middle East, Abstract space, Political public space, Urban movements

Paper type Research paper

\section{Introduction}

Since the conception of the nation-state, the majority of established powers have perceived civil protests as anomalous and unsettling, to be demonised through State media, delegitimised, removed by force, or institutionalised through local and national legislative processes. These urban processes, implicit and underexplored, include the formalisation, de-politicisation and alienation of spaces of resistance.

These strategies are practiced around the world, yet through different mechanisms. In urban contexts, the State imposes increasing temporal, spatial and legal limits on the public practice of politics. Examples of this are the "negotiated management style of protest policing" or the "strict micro-management of demonstrations" (Vitale, 2005, pp. 286-287). Here, protests are normally induced, institutionalised and controlled, to the point that they turn into ineffective and powerless carnivals of dissent. There is a normalisation of civil protests that limits their socio-political influence (Gillham et al., 2013).

In recent years, and in response to social movements such as: the Arab Spring, the Occupy Movement, the Greek protests (known as Syntagma Square), the Ukrainian Euromaidan protests, the 2009 Iranian presidential election protest, the Gezi Park and Taksim Square Movement in Turkey and the Spanish "Indignados Movement", many local governments have begun to formulate and execute legal measures to control public spaces (Fominaya, 2014).

In the Middle East, protests - when they have happened - have been more separate from and antagonistic to the State's power and institutions. Accordingly, they have been more spontaneous, conflictual and influential in threatening the power structures and the political establishment - despite the very high cost that they inflicted on civil society and public services. Roberts (2019) believes that the experience of the Arab Spring and its suppression

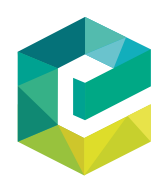

Archnet-IJAR: International Journal of Architectural Research Vol. 13 No. 3, 2019 pp. $483-497$

(c) Emerald Publishing Limited DOI 10.1108/ARCH-03-2019-0054 
$\mathrm{ARCH}$

13,3

484

has shaped, and continues to shape, the politics of many states in the region and beyond. He uses the example of anti-government protests in Morocco in 2016-2017, against corruption, unemployment, police brutality and neglect of the Berber population (Roberts, 2019, p. 16).

After these developments, various local authorities in the Middle East have pushed for a privatisation of public space, while still acting within the limits of local urban regulations. According to Mitchell (2003), the manifestation of power in public space is the requirement of public visibility and democracy (p. 148). Based on Mitchell's (1996) conception of public space, this research will provide the reader with the socio-political atmosphere of the city, through reading its public squares.

Focussing on city squares, Khalaf (2013) traces representations, appropriations and the symbolism of the Pearl Roundabout in Bahrain. He navigates its history from creation through to after-life touching on issues of public space, both real and virtual, as this once anonymous roundabout, renamed and recast, is made, unwittingly, into the symbol of a movement (Khalaf, 2013, p. 265). Khalaf believes that the story of Bahrain's Pearl Roundabout has emphasised - more than any other site of protest in the Arab Spring - the importance of space and the control of it. Beyond the fact that the space of protest was destroyed, public space continues to be contested (Khalaf, 2013, p. 279).

In the case of Cairo, Abaza (2014) believes that the capital has witnessed unprecedented transformations since the January revolution of 2011, including an escalation of war zones and confrontations between protesters and police forces, the militarisation and policing of the urban sphere, and the creation of segregating buffer walls that paralyzed entire areas (Abaza, 2014).

Through these series of collective micro-events, a new spatiality is introduced which blurs the limits between private and public, legal and illegal. This new spatiality transforms the established order of public spaces on a temporary and/or permanent basis. Most likely due to the fear of wider national uprisings, the authorities in these countries are seeking to institutionalise urban movements by limiting or depoliticising their spatiality. This research provides useful material for comparing the shrinking public space available for protest in the west (Occupy Wall Street is the most prominent case) to those of social justice movements globally.

Specifically, this study focusses on Iran and Turkey, in which recent policies and strategies have been proposed and implemented to reduce and possibly neutralise the impacts of urban and political protests. More importantly, these spatialities are transforming the memory of public space, as the paper analysing whether these memories have been accentuated by the radical spatiality of dissent or diminished by the spatiality of control and State domination.

Through a critical analysis of these policies and processes in the case studies of Tehran and Istanbul, this paper presents a contextualised reading of Lefebvre's concept of abstract space, and the process of abstraction as it relates to the alienation of political public space in those two cities. The analysis aims to explain how the abstract space of the State - both universally, and specifically within the Middle Eastern city - aims to homogenise and eliminate any anomaly that threatens its power, leading to the alienation of public spaces from the populous. Furthermore, this paper argues that the scope of these policies is not limited to the physical spatiality of these contested places, as the State aims to recast the spatiality and the memory and the memory of spatial resistance.

As Massey (1994) posits, integrating geography and social science thinking implies a certain way of treating the geographical concepts of space and place. Following this interpretation, the concept of radical spatiality allows to generate a series of dissident and temporal ad hoc urbanism that conducts its construction. The case of "radical spatiality" in Tehran focusses on the spatiality of revolutions and discontents in recent protests and aims to connect them with a current geography of discontent. 
This paper uses historical and discourse analyses of urban policies and political strategies as the methodology with which to approach its case studies. The analysis of Tehran's case is based on a discourse analysis of official documents, media releases, archival references and published research materials. In the case of the Gezi Park Movement, the analysis relies on field research, interviews and ethnographic information insofar as it relates to the strategies and the policies that were implemented because of that Movement. This approach aims to unpack how sequence of events has transformed the meaning and the image of these political places within the urban reality of the city.

It is important to note that this paper aims to sketch possible lines of future research, rather than to give definitive conclusions. This research provides an important contribution to the ongoing discussion surrounding the anti-democratic spatial re-ordering taking place across the world: one which discourages public demonstrations, protests and public deliberation. This paper concludes that regardless of these strategies being applied universally, they fail to respond to contextual particularities and therefore alienate marginalised groups of people from normal forms of political participation and the use of public space for the expression of dissent. Due to this alienation, these policies and strategies may actually produce a differential space of resistance, or a radical new spatiality.

\section{Radical spatiality in Tehran}

Tehran expanded its spatiality of revolutions and discontents through recent protests: specifically, the Islamic Revolution of 1979 and the Green Movement of 2009. According to Ahmad Ashraf (1988), the Islamic revolution aimed primarily at seizing the apparatus of the expanding modern State, in order to export its message and establish an Islamic empire. With the socio-political change of the society, there came a dramatic change to the public spaces in Tehran. In the book "Staging a Revolution", Peter Chelkowski and Dabashi (1999) presented the example of Jaleh Square, which was named Martyrs' Square right after the revolution, as the symbol of the transformation of the identity of public spaces (p. 109). The utopianism of the 1979 revolution is captured in graffiti and posters in urban spaces. "These large-scale painted murals inform the meta-narrative of the Islamic Republic and are also manifestations of visions, accounts, and realities of a unique society in the process of (un) making and (re)defining itself" (Grigor, 2002, p. 37). The existence of a very new regime with new structures could be observed in public spaces of Tehran.

In Post-Revolutionary Tehran, the re-identification of public spaces followed two general streams: first, place names with a direct link to the Shah or to American and British influence were changed, and then, places that recalled the pre-Islamic past. For the first decade after its victory, the Iranian Revolution (1979) was dominated by an uncompromising Islamist ideology, invoking the Islamic and vernacular traditions (Mozaffari and Westbrook, 2018, p. 185). There are many public spaces throughout Tehran that experienced this re-identification after the Iranian Islamic Revolution. Before the 1979 Iranian Revolution, Shahyad Square (as it literally means remembrance of the king) was the place to manifest the glory of Pahlavi monarchy and its associated national identity. The place "earned" its new name - Azadi or Freedom Square - through its role as a significant gathering place for protesters throughout the movement that eventually overthrew the Shah of Iran.

Since the January revolution of 2011, the "Tahrir effect" remains evident, in that it revolutionised the very notion of what a public space is about (Abaza, 2014). As Rabbat (2011) posits, with the creation of wide, straight boulevards as Haussmannian axes that enabled surveillance, military movement and crowd control, a new network of active linkages was created. Years later, protesters poured into the square from these Haussmannian boulevards reclaiming its huge open space as their own (Rabbat, 2011).

Like Tahrir Square, the mere mention of Azadi Square in Tehran evokes images of people gathering to confront an autocratic political system (Mehan, 2016, 2018). By late 
$\mathrm{ARCH}$

13,3

486

1978, Tehran University, Jaleh Square and Azadi Square were perceived as the location of radical thought and urban mobilisation in Tehran. The military government closed Tehran University as a protest site, but mobilisation still occurred there throughout January of 1979 (Parsa, 1989, p. 155). The urban centres of the uprisings, such as Azadi and Enqelab Square in Tehran, became symbolic nodes of power struggles (Ghrawi et al., 2015, p. 3).

Following this perspective, the country's new political identity shaped by new and post-revolution murals through never-ending struggles to define a new identity. This struggle exposed in the Summer of 2009, as one of the most turbulent years in the country's modern history. Iran's Green Movement prompted by contested presidential election results, youthful desire for expression and reform and a collective wave of national political optimism. This movement peaked when hundreds of protestors converged at Azadi Square for the public demonstrations following the Iran's 2009 presidential elections.

It can be argued that the history of Azadi square as a site of mobilisation held a special attraction for Green Movement protesters. However, this history and the images associated with it were re-appropriated during the 2009 movement. The above-mentioned places hold a spatial significance as symbols of the 1979 revolution, since protestors were actively contesting the meaning and memory of that event. Focussing on the re-appropriation and re-politicisation done by urban movements, Deaton (2013) compared the actions of the Green Movement to the transformation of Wenceslas Square during the 1989 movement in Prague (pp. 168-170). According to Asef Bayat (2013) - the Iranian-American sociologist - the Green Movement of 2009 "disclosed the more complex reality of Tehran that is traversed by glaring contradictions and marked by a persistent socio-spatial rebelliousness". In a similar way, Monshipouri and Assareh (2009) believed that just as the 1979 Iranian Revolution was regarded as a model in some parts of the Muslim world, so might 2009s opposition to autocratic rule serve as a regional model (Monshipouri and Assareh, 2009).

Michael Fischer (2010) stated "Repetitions emerge, but with a difference, anxiously conjuring up costumes and slogans of the past to act upon a new historic scene. More often the repetition, including farce and failure, clears the way for the next movement" (p. 497). In the case of Tehran, Bayat (2013) believes that "most of the Green demonstrations occurred in the centre and centre-north of Tehran - a slightly northward move from the 1979 pattern, which had included the centre and centre-south. As the city had expanded and the middle-class grown, the political geography had also shifted. The educated middle classes played a key role in the Green Movement, as they had done in the 1979 revolution” (p. 170). Abrahamian (2010) also presents Azadi Square as one of the important sites of mobilisation in 2009 as follows: "There were vociferous protests in many parts of the country, and Mousavi (a former Prime Minister in the newly established Islamic Republic who after 20 years of political silence announced his intention to run in the 2009 Iranian presidential election) and Karoubi (a presidential candidate in the 2005 and 2009 presidential elections) called for a silent rally to be held at Azadi (Freedom) Square in Tehran on Monday, June 15. Around a million people heeded the call [...] the scene was reminiscent of the rallies held in the same square during the 1979 Revolution" (p. 67).

In the broader context, Khosrokhavar, Franco-Persian Sociologist, in his book - New Arab Revolutions that Shook the World - contextualised the image of "Arab Spring" beyond the Arab world. He theorises about how these recent movements are leave an imprint on Iran's modern quest for democracy (Khosrokhavar, 2016). On 27 December of 2009, when the large demonstrations on the eve of the Shia religious ceremony of Ashura were over, the Green Movement activists suggested to the protestors that they take over the Azadi Square on the anniversary of the 1979 revolution. The State-organised annual mass commemoration starts from the main street in central Tehran and leads to Azadi Square. However, when the day arrived, Iranian Government security forces blocked all routes leading to square. 
With a discourse focussing on solidarity, social movements aim to pursue a common political agenda of change through collective action. Starting from December 2017 and continuing into 2018, a series of public protests occurred in various cities throughout Iran, specifically addressing the daily life of women in public spaces. The recent women's movement in Tehran highlighted the socio-political importance of Revolution (in Persian: Enghelab) Street and Freedom (in Persian: Azadi) Square in building and representing spaces of protests in modern Tehran (Mehan and Rossi, 2019, p. 239). More recently, and especially after the January 2018 protests, one of the key responses of the State within the context of Tehran has been the de-politicisation of public spaces. The local authorities and national government have attempted in multiple ways to limit political protests. In 2018, Tehran's City Council passed a bill to demarcate certain places for protests and political expression. The Iranian Parliament followed suit, delineating a few specific public spaces in Tehran for the specific purpose of political protests, while banning any form of political mobilisation in other urban spaces.

On January 7, the Tehran City Council required the Municipality to identify the appropriate places and announce them in a month. While there was a robust debate about the legality and validity of such ideas in the papers and media, the Ministry of Interior passed a similar bill, requiring City Councils and regional Municipalities to identify "appropriate" locations of public protests. On June 10, 2018, the Minister's Committee announced 12 locations where authorised protests could be held in the capital. According to Iran's semiofficial ISNA news agency and Etemad Newspaper, the protest zones in Tehran include the Shiroudi, Dastjerdi, Takhti, Motamedi and Azadi sports stadiums; the Goftegoo, Taleqani, Velayat, Pardisan, Honarmandan and Shahr public parks; and an area near the parliament building in the capital's Baharestan neighbourhood[1]. Tehran's City Council members proposed these locations (inspired by western democratic societies) as locations for people to be "seen and heard" by "other inhabitants", and to identify appropriate places that have the "capacity for police protection and security, the emergency services" and preventing traffic jams (see Figure 1)[2].

By shifting the spatiality of resistance to a demarcated and controlled space, the State in Iran aimed to change the sociability and urbanity of specific localities of protests. In the same way, the Turkish State has aimed to dominate the key symbolic urban spaces of Istanbul, Taksim Square and Gezi Park. The context might be different, but the objective is the same: the re-identification of public spaces and the re-assertion of the State's "nationalized image of social space" (Khosrokhavar, 2016, p. 40); one that reflects "the manifestations of visions of the unique society in the process of redefining itself" (Brenner, 2004 , p. 37). In the case of Istanbul, it was not a national theocratic revolution - like the Islamic Revolution of Iran - that triggered this desire to re-appropriate and dominate radical spatialities of the city. Instead, it was the peculiar combination of State ideologies that drove it to rebrand the city and the country with its hegemonic images of religion and national identity, intensification of neoliberal urban developments and also an increasing tendency towards the intolerance of difference.

The next section focusses on the relationship between the State-led urbanisation of the Gezi Park Development Project, and the anti-urban Gezi Park Movement, and how the dialectic between the two transformed the radical spatiality and memories of Istanbul's complex urban reality.

\section{The Gezi Park Movement and alienation of spatiality of politics in Istanbul}

The State's ideological re-assertion onto the city and its appropriation of public spaces have been central in political reformations and revolutions, and as discussed in the previous section, and witnessed around the world (Grigor, 2002; Low and Smith, 2013).

The Gezi Park Movement started on the 27th and 28th of May 2013 with a protest by environmental activists against bulldozers ready to excavate the park and its trees 

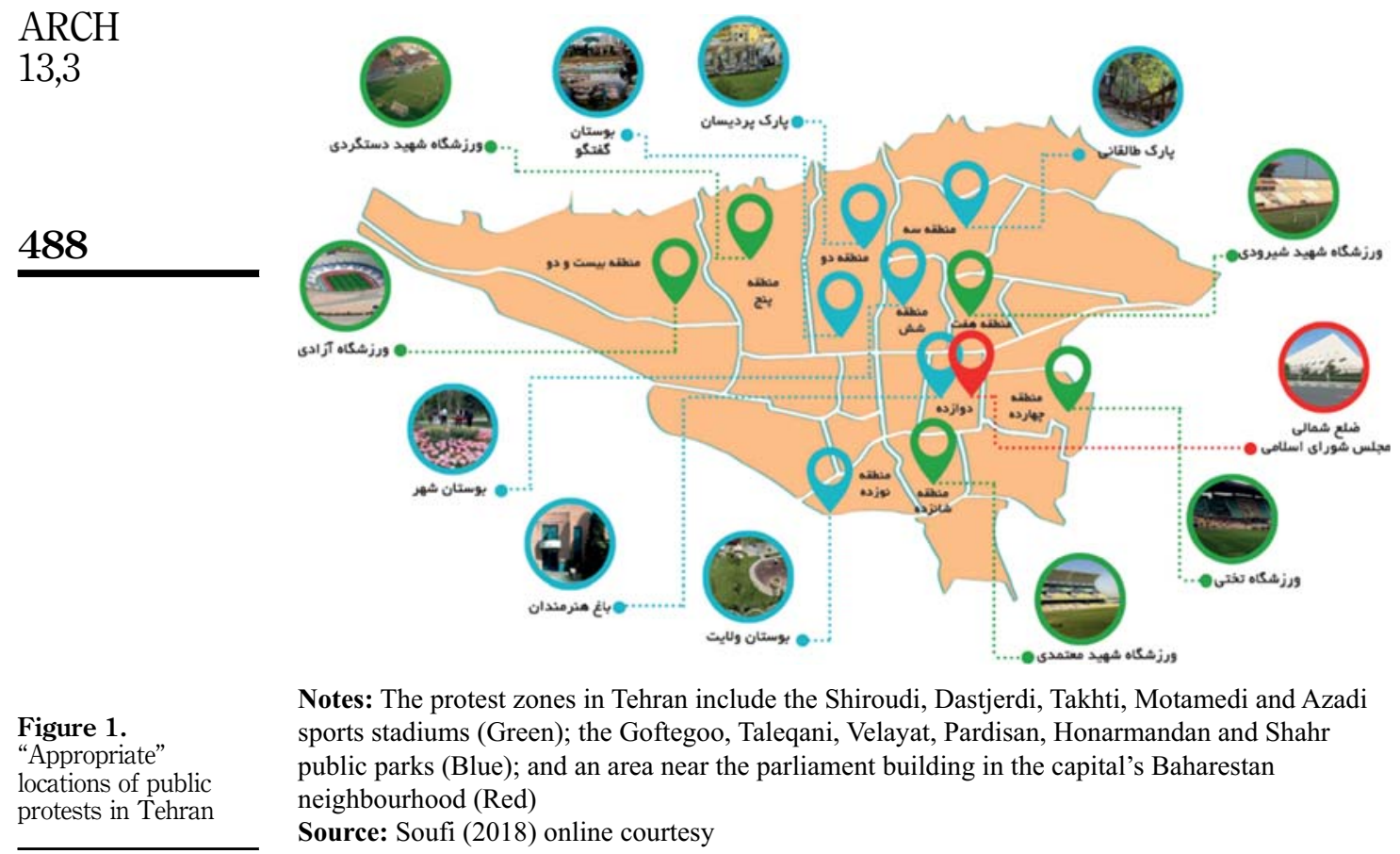

Notes: The protest zones in Tehran include the Shiroudi, Dastjerdi, Takhti, Motamedi and Azadi sports stadiums (Green); the Goftegoo, Taleqani, Velayat, Pardisan, Honarmandan and Shahr public parks (Blue); and an area near the parliament building in the capital's Baharestan neighbourhood (Red)

Source: Soufi (2018) online courtesy

(Polat and Subay, 2016). This was the catalyst for a much wider movement that had been efflorescing, in different forms, for a long time as a response to the new urban policies imposed by State and the market (Elicin, 2014; Gül et al., 2014; Lelandais, 2016; Örs, 2014). The Gezi Park Movement, its spatiality, its socio-political dimensions and consequences, all have been extensively discussed in the literature and the media (Ay and Miraftab, 2016; Batuman et al., 2016; Çoban, 2016; Elicin, 2017; Eryılmaz, 2016; Inceoglu, 2015; Lelandais, 2016; Odabaş and Reynolds-Stenson, 2017). Therefore, this section investigates the Taksim Square and Gezi Park Development Project as the State's tool for imposing its ideological image, how that triggered the Gezi Park Movement, and how the entire process was aimed at constructing a new urban identity and diminishing the memory of the place and its historical roots. In this process, the State's subject of control was not the urban poor, nor any specific demographic group. Instead, it was the memory and identity of the place that was threatening to the neoconservative ideology of an increasingly powerful State. Aksoy (2017) elaborates further on who, or more accurately what, was marginalised through the Gezi Park Development Project:

Thus, in the Gezi context, "ordinary" people, from very different walks of life, from different political leanings, ethnic backgrounds, socio-economic groups, life-style choices, and so on, came together, and by doing so, they discovered their hitherto obscured qualities, such as being able to engage with each other, in solidarity across identity and political divides. The way the urban regime had been ordering identities among the city's population was totally disrupted. (p. 20)

While the construction of the 94th shopping mall of Istanbul (at the time of the movement in 2013) was part of the Taksim Square and Gezi Park Development Project, the redevelopment as a whole was seen as a crucial step in the commodification process of the city, one which had been permeating its central public spaces (Kuymulu, 2013; Lelandais, 2016; Manfredini et al., 2017). It was read as the ultimate extension of the space of consumption, entertainment and leisure - uncannily recombined with an institutional and nostalgic interpretation of a 
nationalistic aesthetic - one that is rapidly transforming the character of the area and the centre of Beyoğlu district (Arat, 2013; Eken, 2014; Gül et al., 2014).

The Gezi Park Development Project was a direct reference to the Ottoman Empire and its past glory and the neoliberal-Islamic hegemony of the ruling AK Party (Polat and Subay, 2016). The project was designed to impose and reflect the nostalgia for an Ottoman history and rebrand the imperial part of Istanbul as a specifically Turkish urban quarter. It was built to reflect the State's authority and power, Turkishness, Turkish identity and market logic, something that Moudouros (2014, p. 430) describes as "one of the latest works of simulation in which the conservative past and contemporary capital consummate their affair". Here, the process is seen as the peculiar marriage of the State's traditionalist and religious ideology with neoliberalism - a form of Turkish neo-dirigisme - for a new space of consumption. Even after the protests, the prime minister himself contended that "Turkey is not only [current] Taksim Square and Gezi Park", as distinct and symbolic places (Eken, 2014, p. 184). Taksim Square and Gezi Park needed to be reconceived and spatially assimilated into the Turkish culture to reflect the so-called true identity of Turkey as the - homogenous - Turkish Muslim nation-state.

Within the discourse of authorities and politicians then, Gezi Park itself was seen negatively, as the space of difference (Karasulu, 2014). Difference, as of maximal difference in a Lefebvrian sense, is considered a threat to the rationality of State. The acceptance of difference for one State can be an ideological hindrance for another, as each society, and hence each State, produces its own social space and relations (Moudouros, 2014). It is extensively argued that difference within the context of Taksim Square and Gezi Park was often misrepresented and ideologically described as the lack of "safety and hygiene" (Ete and Taştan, 2014), which was fostering crime, immoral behaviour and even perversion. The manufactured necessity of removing this element is often attributed to these forceful descriptions. Municipal officers and senior politicians, including the prime minister of the time, labelled the park as the place of "undesirables", such as transsexuals, prostitutes and drug dealers (Lelandais, 2016, p. 300). Such was the vision of designers and politicians, and part of implementing a well-established logic and aesthetic of neoliberal urbanism, a process that Cuthbert depicts as a form of "sterilization of urban space by removing any historical referents, building on landfill and in the purging of nature and the sanitization of social space through corporate architectural ideology" (p. 298).

The Gezi Park Development Project aimed to generate and produce the spectacle of consumption that is commonplace around the world, and had similar agents, forces, aims and consequences as elsewhere (Cuthbert, 1995; Smith, 2002), yet with a specific nationalist and nostalgic twist, so as to be the specific ethno-architecture of Turkish State. Gezi Park and Taksim Square are still symbolic, political and radical spatialities of resistance, as the Government of Istanbul and the Turkish State fortify the place any time that there is the possibility of protest or demonstration.

The abstract space of (the) State, when failing to dominate and reassert its ideological and colonial logic of ethno-spatiality, relies on militarism, violence and social ordering and control. The space around Taksim area and Gezi Park during and after the Gezi Park Movement was inscribed with anti-market and anti-state graffiti and sentiments. Reacting to these sentiments, and since the end of the Gezi Park occupation, the presence of police and militaristic presence of power in the square has been a constant reminder of State's power over this symbolic space, as observed during our field work. Following the protests, the State has systematically banned, stopped or interrupted any form of protest, demonstration or vigil in and around the area. This includes the May Day demonstrations (www.euronews. com/2018/05/01/turkish-trade-unions-angry-at-corralled-may-day-protests-and-blockade-oftaksim-square), LGBT rights protests (www.independent.co.uk/news/world/middle-east/ istanbul-pride-eleven-arrests-official-ban-march-parade-turkey-lgbt-a8426656.html) and
Political public space in the Middle East 
$\mathrm{ARCH}$

13,3

490

Mothers' Vigil (www.dw.com/en/istanbul-riot-police-break-up-saturday-mothers-vigil/a45227121). These explicit forms of control did not replace, but merely added to the soft methods of cleansing and domination, specifically aiming to erase the memories of the movement and its roots. Describing this process, Evered (2018) states:

Municipality workers then performed a dramatic landscaping makeover - one contrasting sharply with the park's pre-May 2013 state of relative neglect. They rolled fresh turf throughout, planted flowers, constantly watered and added banners. By then, passers-by walked briskly on adjacent sidewalks and would-be spectators could see and photograph the park but were otherwise banned. (p. 159)

The May Day demonstrations played a significant role in building the foundation of the Gezi Park Movement. On May Day of 2013, a few days before the beginning of the movement, the square "was restricted for labour unions and left-wing parties", and "the government put forward the pedestrianisation of Taksim Square as the rationale for the ban". To this date, and as of the latest May Day of 2018, the State has still not allowed unions or grassroots organisations to protest in Taksim Square, barricading the place with fences and armies of police and informal State agents, while allowing a staged, State-sponsored and formalised demonstration to take place instead.

The opposition of the Gezi Park Movement to the development project was a reaction to an overdetermined and culturally loaded project, reflecting the strong Islamic hegemony of the State power vis-à-vis the indeterminacy of Gezi Park, which was at least seen as an open space of difference, an architecturally neutral urban space with much less explicit celebratory qualities. Although the space may be considered architecturally insignificant, it has always been highly political and embodied in its legacy as the first public park of a modern Turkey, with its foundational ideas of pluralism. While Gezi Park was as differential, indeterminate and mundane, it was precisely these qualities that could not be traded for the State-sponsored space of iconography, consumption and commodification.

After almost six years, and at the time of writing this paper, Gezi Park is still a radical spatiality of dissent, despite the fortification and the perpetual and slow encroachment of the "renewal project". The Ataturk Cultural Centre demolition was completed on 30 May 2018, almost at the same time as the anniversary of the Gezi Park Movement. While one of the symbols of the old secular Istanbul has been disappearing, a new Mosque is rising on south-western corner of Taksim Square, where the police and security forces were deployed during and after the movement. Although the park itself is standing its ground, the height of new cranes, buildings and symbols of modern, Ottomanised architecture are attempting to dwarf Gezi Park and what it stood for during and before the movement.

Taksim Square's role as the location for uniting different movements and groups is now diminished physically, but the geography of dissent is alive in the memories of Istanbul's people. There has been a scalar transformation of the physical geography of resistance, as new and more localised public spaces have been activated. This was seen in the Bostan Forums, an urban phenomenon in which many neighbourhood parks became the loci for public debate and the expression of political dissent after the Gezi Park Movement (Erensü and Karaman, 2017). Despite all the State's attempts at erasure these processes are parts of a common narrative, one that will be analysed in the next section through the lens of "abstract space".

\section{The abstract space and state sovereignty}

As Sassen (2005, p. 32), Harvey (2012), Madanipour (2006), Olds (2002) and (Dovey, 2005) argue, the globalisation of urbanisation based on the neoliberal economy has "neutralised [the] distance and place" and resulted in a mass production of cities without local identities or urbanity. What some scholars see as the root of this aspect of globalisation is the political economy and its influence on the process of urbanisation through iconography and urban 
image making. This process reflects both the symbolic power of the state - the global state - and abstract space, and also the competitiveness of the city within the global urban market. Urbanisation is reduced to a production of image making, branding and marketing of place, one primarily for consumption rather than to use or to live in. The state has a pivotal role in this process, as Lefebvre (1991) says: "in this sense reduction and reductionism appear as tools in the service of the state and of power: not as ideologies but as established knowledge; not in the service of any specific state or government, but rather in the service of the state and power in general" (p. 106).

An urban space as the locus of heterogeneity, anonymity and spontaneous activity poses a significant challenge to the status quo ante of a centralised State and its hegemonic establishment of a specific territory. Harvey (2008, p. 40) declares that "Lefebvre was right to insist that the revolution has to be urban, in the broadest sense of that term, or nothing at all". To understand this and explain the process that has occurred in Tehran and Istanbul, we use the Lefebvrian concepts of abstract space and the abstraction process. Lefebvre (1991, p. 86) traces the development of abstract space "as a product of violence and war" and concludes "it is political; instituted by the state, it is institutional". Lefebvre (1991, p. 285) depicts it as a violent instrument of state which "indeed [...] serves those forces which make a tabula rasa[3] of whatever stands in their way" and it is planned and designed through the logic of the political state, money, and power that "allows the state to introduce its presence, control, and surveillance in the most isolated corners" (Lefebvre, 2003, p. 86).

The implementation of this ideology, and to make a tabula rasa of the city, is violent. This violence is done both explicitly, through material intervention (e.g. urban redevelopment processes) and control (e.g. law enforcements through actual policing of space and militarisation of the city) and implicitly, through national and local policies, such as "revitalisation" programmes that result in gentrification, displacement, segregation and deprivation (Atkinson and Bridge, 2004, p. 90; Smith and Williams, 2013, p. 92; Mehan, 2017, p. 210). The antagonism towards the state's ideology and its abstract space, intended to further solidify and materialise the economic and financial ambitions of the government, is palpable in our analysis of the Gezi Park Movement and the institutionalising of Tehran's radical spatiality, also reflected in the performative and visual symbolism of the movement (Ay and Miraftab, 2016, p. 571).

Abstract space in action tends towards the abstraction of the space fully, meaning in totality and in all directions. This process is often left unchallenged, as the state is perceived as of the people, an element of the society that is "the sole planning agent, since it possesses some privileges de facto and some prerogatives de jure, such as power to regulate land use in the whole city through urban law (e.g. zoning ordinances), as well as the formal power to enforce its determinations ('legal monopoly of violence', police)" (Souza, 2006, p. 328). In the case of Tehran, the State aims to eliminate any form of threatening heterogeneity, and constantly seeks to homogenise the city by institutionalising its radical spatiality and shifting the spatiality of resistance to a demarcated and controlled one. This strategy is discussed at length by Mitchell and Staeheli (2005, p. 797) within the legislative context of the USA. They note, for example, that "So too had the construction of 'protest pens' (or fences to keep protesters in particular areas and away from others) become a key strategy for policing dissenting political speech”.

This kind of approach was seen throughout the Taksim Square and Gezi Park Development, a transformation aimed at homogenising the centre through a process of "revitalisation": meaning, a neoliberal urban vision that extends the existing landscape of consumption (Batuman et al., 2016, p. 190). The antagonism towards the state's ideology and its abstract space is palpable throughout the qualitative data we gathered in Istanbul, and was also reflected in the performative and visual symbolism of the movements in Iran (Ay and Miraftab, 2016, p. 571). 
$\mathrm{ARCH}$ 13,3

As Harmanşah (2014) indicates, the State approaches Gezi Park and Taksim Square through a lens of uncritical historicism, to reinvent the Turkish and more so Istanbul's identity in line with its neoliberal and Islamic ideology:

Any kind of uncritical historicism about public space is susceptible to appropriation by today's neoconservative, authoritarian discourse of the capitalist state that would not hesitate to put a blanket over painful memories of that space, marginalize opposing voices from the public sphere and exercise greater control over city's thus gentrified and commercialized spaces. (p. 129)

The space around the Taksim area and Gezi Park during and after the movement was inscribed by anti-market and anti-state graffiti and sentiments. This is ironically like both the institutionalised revolutionary appropriation of public places by the Iranian State and the anti-government graffiti of the Green Movement. One was prescribed by the ideology of a theocratic State, the other erased by the State to assign a new identity, as Evered (2018) explains:

Pursuing erasure, officials revealed profound continuities linking physical with discursive practices to suppress opposition; engaging simultaneously in policing, brutally confronting and scattering open assemblies, on the one hand, and purging dissident narratives from public view and subsequent recollection, on the other hand. (p. 157)

This explains the role of the Gezi Park Movement against the underlying socio-political motives of the State-led projects which was a mechanism to reinstate the role of space as the locus of capital accumulation, exchange value and specifically in the case of Tehran and Istanbul, as the place of re-identification of the State and its image. Both Lefebvre (1996) and Harvey $(2001,2012)$ point out that, within capitalist society, the regeneration and reproduction of urban space is tightly related to the accumulation of capital and exchange value, in contrast to the use value of urban space. Lefebvre (1996) argues that:

City and urban reality are related to use value. Exchange value and the generalization of commodities by industrialisation tend to destroy it by subordinating the city and urban reality which are refuges of use value, the origins of a virtual predominance and revalorization of use. (p. 67)

Through the urban movements and protests, the above process of commodification, nationalisation and abstraction was resisted at its core. The moment of negation, confrontation and appropriation of Gezi Park or the public places of Tehran became a legitimised urban practice of the time, shifting the discourse and the meaning of public space within the context of Tehran and Istanbul. This instigated a process of repoliticisation of space, the city and urban practices. The new urban practice did not produce a material and site-limited architecture; rather, it produced a different urban reality through its radical spatiality that transformed the physical, mental and social space of the city, and to this date, its effects on the perception of and possibilities for a different city can be felt despite a recent apparent shift of national politics towards more totalitarian and ideological governance.

Although the State has in both Tehran and Istanbul attempted to and still attempts to explicitly supress and diminish resistance, implicit and institutional forms of control and surveillance are dominating both States' approach to the radical spatiality of resistance and are ultimately more violent and divisive. Explicit suppression of dissent has cost Middle Eastern States profoundly, and mainly resulted in further protests and demonstration. In contrast, the recent attempts to formalise, institutionalise and induce the dissent can in fact damage the civil and urban rights movements more deeply, as the State alienates the marginalised groups from their own struggles through excessive policing, surveillance and co-optation of protests and movements. It is vital that radical scholars, academics, architects and planners rethink and reimagine the spatiality of resistance in light of these 
new developments. Mitchell and Staeheli (2005) summarise the concluding points of this arguments as they argue:

The permit system seems to be in the process of being replaced by a geography defined by the corralling of protesters, an urban landscape marked by fences, checkpoints, fenced-off "no-protest" zones (which can be anything from a few blocks to a few kilometres wide), and the establishment of official "protest pens" to hold all those who may disagree with the actions of their government or other powerful public players. As we suggested at the outset, the politics of the public space can shape the politics in public space, but the reverse is also true: the politics in public space has now

become a prime determinant of the politics of public space. (p. 811)

\section{Comparisons and conclusions}

Through the urban movement, the above process of commodification and abstraction was resisted at its core. The moment of negation, confrontation and appropriation of the park, became a legitimate urban practice, shifting the discourse and the meaning of public space within the context of Istanbul. This instigated a re-politicisation of space, the city and urban practices. The new urban practice did not produce a durable material and site-limited architectural building; rather, it produced a differential urban reality that transformed the physical, mental and social space of Istanbul, and to this date, its effects on the perception of and possibilities for a different city can be felt despite a recent apparent shift of national politics towards more totalitarian and ideological governance. The Gezi Park Development Project was seen as an imposition of the State's ongoing ideological repositioning and faced strong opposition from many individuals, groups and organisations, some antagonistic towards each other, and some with consensus, but all unified to produce a peculiar geography of resistance that not only challenged the abstract space and urban ideology of the State, but injected new meanings into Istanbul's urban reality.

The strategies and policies in modern Tehran though parallel to the case of Istanbul are different in their approach. Instead of changing the nature of the protest spaces, the State in Tehran tries to shift the spatiality of resistance to a demarcated and controlled one. The current social movements in Tehran were both a reaction to the events of the time and continuation of a process that began before the Islamic Revolution of 1979 go back to the creation of the country as a nation-state. This process has aimed to homogenise a rather heterogeneous, multi-ethnic, multi-lingual and fluid society, one which resisted the dominant mono-cultural narrative imposed by the State. The public space and all the in-between places in metropolitan cities like Tehran are the loci of this "quiet encroachment" of the society (Lefebvre, 2003, p. 545) against this narrative. Here, we analysed the discourse around these processes, aiming to highlight how such policies and the struggles against them had led to alienation of the public from the city and further militarised the urban reality of Tehran, as many marginalised groups like women would not be able to express themselves freely in demarcated, controlled and formalised spaces of protest. These groups "contest the meaning of order, control of public space, control of public and private goods, and the relevance of modernity" (Bayat, 2006, p. 546), while opposing the dominant abstract space of the State, and its masculine, pervasive and violent aspects.

The existing research in social movement theory suggests that communities have reclaimed public space during the global justice movement. Even in instances where governments and companies shrunk public space, the absences of the squares that once hosted these revolutions become a powerful symbol in spite of government repression. In this regard, the public space can be defined as the machine of disruption that is used by democrats against the authoritarian regime or used by the authoritarian regime to disrupt the forming of an urban social network outside of its control. Through neoliberal urban policies, redevelopment projects, urban design and also fortification of public space, States 
$\mathrm{ARCH}$ 13,3

aim to make the place undesirable for resistance, rather than providing a desirable - and controlled - place of protest.

In the cases of Istanbul and Tehran, yet again, the emerging forms of control and domination by the State over the public spaces have failed, as according to Mitchell and Staeheli (2005, p. 810) "dissent has become resistance". Not only are the movements resistant to an ideological cleansing of the physical space, or a normalising of protest as a tool to sustain the oppression, but they are resistant to the erasure of memories and deep-rooted urban identities of radical spatialities.

\section{Notes}

1. See Etemad Newspaper (published on 12 June 2018 in Farsi): www.etemadnewspaper.ir/1397/03/22/ Main/PDF/13970322-4108-1-1.pdf

2. See Etemad Newspaper (published on 12 June 2018 in Farsi): www.etemadnewspaper.ir/1397/03/22/ Main/PDF/13970322-4108-4-2.pdf

3. Tabula rasa (Latin: "scraped tablet" - i.e. "clean slate") in epistemology (theory of knowledge) and psychology; a supposed condition that empiricists attribute to the human mind before ideas have been imprinted on them by the reaction of the senses to the external world of objects (Encyclopredia Britannica, 2019).

\section{References}

Abaza, M. (2014), "Post January Revolution Cairo: urban wars and the reshaping of public space", Theory, Culture and Society, Vol. 31 Nos 7-8, pp. 163-183.

Abrahamian, E. (2010), "I am not a speck of dirt, I am a retired teacher", in Hashemi, N. and Pastel, D. (Eds), The People Reloaded: the Green Movement and the Struggle for Iran's Future, Melville House, New York, NY, pp. 60-71.

Aksoy, A. (2017), "What emerged in the Gezi Park occupation in Istanbul?", in Hemer, O. and Persson, H.A. (Eds), In the Aftermath of Gezi, Palgrave Macmillan, Cham, pp. 17-34.

Arat, Y. (2013), "Violence, resistance, and Gezi Park", International Journal of Middle East Studies, Vol. 45 No. 4, pp. 807-809.

Ashraf, A. (1988), "Bazaar-mosque alliance: the social basis of revolts and revolutions", International Journal of Politics, Culture and Society, Vol. 1 No. 4, pp. 538-567.

Atkinson, R. and Bridge, G. (2004), Gentrification in a Global Context, Routledge, London.

Ay, D. and Miraftab, F. (2016), "Invented spaces of activism: Gezi Park and performative practices of citizenship", in Grugel, J. and Hammett, D. (Eds), The Palgrave Handbook of International Development, Springer, London, pp. 555-574.

Batuman, B., Baykan, D.A. and Deniz, E. (2016), "Encountering the urban crisis: The Gezi event and the politics of urban design", Journal of Architectural Education, Vol. 70 No. 2, pp. 189-202.

Bayat, A. (2006), "From 'dangerous classes' to 'quiet rebels': politics of the Urban Subaltern in the Urban Global South", in Gibson, T. and Lowes, M.D (Eds), Urban Communication: Production, Text, and Subtext, Rowman \& Littlefield International, Lanham, MD.

Bayat, A. (2013), Battlefield Tehran Life as Politics: How Ordinary People Change the Middle East, Stanford University Press., Stanford, CA, pp. 153-175.

Brenner, N. (2004), "The globalization debates: opening up to new spaces?", in Brenner, N. (Ed.), New State Spaces: Urban Governance and the Rescaling of Statehood, Oxford University Press, Oxford, pp. 27-68.

Chelkowski, P. and Dabashi, H. (1999), Staging a Revolution: The Art of Persuasion in the Islamic Republic of Iran, New York University Press, New York, NY. 
Çoban, B. (2016), "Occupy movements, alternative new media, and utopia: the Gezi resistance and activist citizen journalism", in Çoban, B. (Ed.), Social Media Revolution: An Introduction, Lexington Books, London, pp. 73-97.

Cuthbert, A.R. (1995), "The right to the city: surveillance, private interest and the public domain in Hong Kong", Cities, Vol. 12 No. 5, pp. 293-310.

Deaton, C.D. (2013), The City Cannot Be Occupied: Urban Movements and Revolutionary Memory in Paris, Prague, and Tehran, University of Illinois at Chicago, Chicago, IL.

Dovey, K. (2005), Fluid City: Transforming Melbourne's Urban Waterfront, Psychology Press, Sydney.

Political public space in the Middle East

Eken, B. (2014), "The politics of the Gezi Park resistance: against memory and identity", South Atlantic Quarterly, Vol. 113 No. 2, pp. 427-436.

Elicin, Y. (2014), "Neoliberal transformation of the Turkish city through the urban transformation act", Habitat International, Vol. 41, January, pp. 150-155.

Elicin, Y. (2017), "Defending the city: Taksim solidarity", Journal of Balkan and Near Eastern Studies, Vol. 19 No. 2, pp. 105-120.

Encyclopaedia Britannica (2019), available at: www.britannica.com/topic/tabula-rasa (accessed 29 September 2019).

Erensü, S. and Karaman, O. (2017), "The work of a few trees: Gezi, politics and space”, International Journal of Urban and Regional Research, Vol. 41 No. 1, pp. 19-36.

Eryılmaz, Ç. (2016), "The spatial analysis of Gezi Movement in Turkey", in Lopes, J.T. and Hutchison, R. (Eds), Public Spaces: Times of Crisis and Change, Emerald Group Publishing, pp. 191-219.

Ete, H. and Taştan, C. (2014), "The Gezi Park protests: a political, sociological and discursive analysis”, SETA Foundation for Political, Economic and Social Research.

Evered, K. (2018), "Erasing the place of dissent: inscriptions and eliminations of Gezi Park graffiti", Area, Vol. 51 No. 1, pp. 155-165.

Fischer, M.M.J. (2010), “The rhythmic beat of revolution in Iran”, Cultural Anthropology, Vol. 25 No. 3, pp. 497-543.

Fominaya, C.F. (2014), Social Movements and Globalization: How Protests, Occupations and Uprisings are Changing the World, Macmillan International Higher Education, London.

Ghrawi, C., Masjedi, F., Fuccaro, N. and Freitag, U. (2015), Introduction Urban Violence in the Middle East: Changing Cityscapes in the Transition from Empire to Nation State, Berghahn Books, New York, NY.

Gillham, P.F., Edwards, B. and Noakes, J.A. (2013), "Strategic incapacitation and the policing of Occupy Wall Street Protests in New York City", Policing and Society, Vol. 23 No. 1, pp. 81-102.

Grigor, T. (2002), "(Re)claiming space: the use/misuse of propaganda murals in Republican Tehran”, No. 28, International Institute of Asian Studies Newsletter.

Gül, M., Dee, J. and Nur Cünük, C. (2014), "Istanbul's Taksim Square and Gezi Park: the place of protest and the ideology of place", Journal of Architecture and Urbanism, Vol. 38 No. 1, pp. 63-72.

Harmanşah, Ö. (2014), "Urban utopias and how they fell apart: the political ecology of Gezi Parkı", in Özkırıml, U. (Ed.), The Making of a Protest Movement in Turkey: \#Occupygezi, Palgrave Pivot, London, pp. 121-133.

Harvey, D. (2001), Spaces of Hope, Edinburgh University Press, Edinburgh.

Harvey, D. (2008), "The right to the city", The City Reader, Vol. 53, pp. 23-40.

Harvey, D. (2012), Rebel Cities: From the Right to the City to the Urban Revolution, Verso Books, London and New York, NY.

Inceoglu, I. (2015), "Encountering difference and radical democratic trajectory: an analysis of Gezi Park as public space", City, Vol. 19 No. 4, pp. 534-544.

Karasulu, A. (2014), "If a leaf falls, they blame the tree': scattered notes on Gezi resistances, contention, and space", International Review of Sociology, Vol. 24 No. 1, pp. 164-175. 
$\mathrm{ARCH}$ 13,3

Khalaf, A. (2013), "Squaring the circle: Bahrain's Pearl Roundabout", Middle East Critique, Vol. 22 No. 3, pp. 265-280.

Khosrokhavar, F. (2016), “The Iranian Green Movement”, in Khosrokhavar, F. (Ed.), New Arab Revolutions That Shook the World, Chapter 1, Routledge, New York, NY, pp. 21-28.

Kuymulu, M.B. (2013), "Reclaiming the right to the city: reflections on the urban uprisings in Turkey", City, Vol. 17 No. 3, pp. 274-278.

Lefebvre, H. (1991), The Production of Space (translated by Nicholson-Smith, D.), Blackwell., Oxford.

Lefebvre, H. (1996), Writings on Cities, Blackwell, Cambridge, MA.

Lefebvre, H. (2003), The Urban Revolution, Trans (translated by Bononno, R.), University of Minnesota Press, Minneapolis, MN.

Lelandais, G.E. (2016), "Gezi protests and beyond: urban resistance under neoliberal urbanism in Turkey”, in Mayer, M., Thörn, C. and Thörn, H. (Eds), Urban Uprisings, Springer, London, pp. 283-308.

Low, S. and Smith, N. (2013), The Politics of Public Space, Routledge, New York, NY.

Madanipour, A. (2006), "Roles and challenges of urban design", Journal of Urban Design, Vol. 11 No. 2, pp. 173-193.

Manfredini, M., Zamani, F. and Leardini, P. (2017), "Instances of emerging agonistic spatialities in the contemporary city: the production of differential geographies in the public space of Istanbul", Asian Journal of Humanities and Social Studies, Vol. 5 No. 5, pp. 281-291.

Massey, D. (1994), Space, Place, and Gender, Polity Press, Cambridge.

Mehan, A. (2016), "Blank Slate: squares and political order of city", Journal of Architecture and Urbanism, Vol. 41 No. 3, pp. 210-220.

Mehan, A. (2017), “'Tabula Rasa’ planning: creative destruction and building a new urban identity in Tehran”, Journal of Architecture and Urbanism, Vol. 40 No. 4, pp. 311-321.

Mehan, A. (2018), "Making heterotopia: Azadi Square as the palimpsest of political memory", 33rd Annual Middle East History and Theory (MEHAT) Conference, University of Chicago, Chicago, IL, April.

Mehan, A. and Rossi, U. (2019), "Multiplying resistance: the power of the urban in the age of national revanchism", in Jacobs, K. and Malpas, J. (Eds), Philosophy and the City: Interdisciplinary and Transcultural Perspectives, Rowman \& Littlefield International, London, pp. 233-245.

Mitchell, D. (1996), "Introduction: public space and the city", Urban Geography, Vol. 17 No. 2, pp. 127-131.

Mitchell, D. (2003), The Right to the City; Social Justice and the Fight for Public Space, The Guilford Press, New York, NY.

Mitchell, D. and Staeheli, L. (2005), "Permitting protest: parsing the fine geography of dissent in America”, International Journal of Urban and Regional Research, Vol. 29 No. 4, pp. 796-813.

Monshipouri, M. and Assareh, A. (2009), "The Islamic Republic and the Green Movement: coming full circle", Middle East Policy Council, Vol. XVI No. 4, available at: www.mepc.org/islamic-republicand-green-movement-coming-full-circle (accessed 29 September 2019).

Moudouros, N. (2014), "Rethinking Islamic Hegemony in Turkey through Gezi Park", Journal of Balkan and Near Eastern Studies, Vol. 16 No. 2, pp. 181-195.

Mozaffari, A. and Westbrook, N. (2018), "Designing a revolutionary habitat: tradition, heritage and housing in the immediate aftermath of the Iranian Revolution - continuities and disruptions", Fabrications, Vol. 28 No. 2, pp. 185-211.

Odabaş, M. and Reynolds-Stenson, H. (2017), "Tweeting from Gezi Park: social media and repression backfire”, Social Currents, Vol. 5 No. 4, pp. 1-21.

Olds, K. (2002), Globalization and Urban Change: Capital, Culture, and Pacific Rim Mega-projects, OUP Catalogue, Oxford. 
Örs, İ.R. (2014), "Genie in the bottle: Gezi Park, Taksim Square, and the realignment of democracy and space in Turkey", Philosophy \& Social Criticism, Vol. 40 Nos 4-5, pp. 489-498.

Parsa, M. (1989), Social Origins of the Iranian Revolution, Rutgers University Press, London.

Polat, F. and Subay, O.O. (2016), "Political movement by apolitical activist: Gezi Park protests", European Scientific Journal, Vol. 12 No. 8, pp. 106-120.

Rabbat, N. (2011), "Circling the square”, Artforum, April, pp. 182-191.

Roberts, A. (2019), "The fate of the Arab Spring: ten propositions", Asian Journal of Middle Eastern and Islamic Studies, Vol. 12 No. 3, pp. 1-17.

Sassen, S. (2005), "The global city: introducing a concept", The Brown Journal of World Affairs, Vol. 11 No. 2, pp. 27-43.

Smith, N. (2002), "New globalism, new urbanism: gentrification as global urban strategy", Antipode, Vol. 34 No. 3, pp. $427-450$.

Smith, N. and Williams, P. (2013), Gentrification of the City, Routledge, London.

Soufi, A. (2018), "Hedayat-e Tajamoaat (in Farsi)", Etemad Newspaper, available at: www. etemadnewspaper.ir/1397/03/22/Main/PDF/13970322-4108-1-1.pdf (accessed 29 September 2019).

Souza, M.L. (2006), "Social movements as 'critical urban planning' agents", City, Vol. 10 No. 3, pp. 327-342.

Vitale, A.S. (2005), "From negotiated management to command and control: how the New York Police Department polices protests", Policing \& Society, Vol. 15 No. 3, pp. 283-304.

\section{Further reading}

Brenner, N., Jessop, B., Jones, M. and Macleod, G. (2008), State/Space: A Reader, John Wiley \& Sons, Oxford.

Tamari, S. (2011), "Confessionalism and public space in ottoman and colonial Jerusalem", in Davis, D.E. and De Duren, N.R.L. (Eds), Cities and Sovereignty: Identity Politics in Urban Spaces, Indiana University Press, Bloomington, IN, pp. 59-82.

\section{Corresponding author}

Farzad Zamani can be contacted at: fzam465@aucklanduni.ac.nz

For instructions on how to order reprints of this article, please visit our website: 